\title{
Revealed Comparative Advantage Analysis Based on VEC models in Chinese Capital-technology-intensive Industry
}

\author{
Ji-ping WANG ${ }^{1, *}$ \\ 1,* School of Management, Wuhan Textile University, P.R., China
}

Keywords: Chinese Capital-technology-intensive Products, Revealed Comparative Advantage, GDP per capita and households deposits, Vector Error Correction models.

Abstract. We investigate the relationships among revealed comparative advantages of Capital-technology-intensive industry, GDP per capita and households deposits in China. With the non-stationary sequences of global Capital-technology-intensive products' exports, we constructed the vector error correction model with serial correlation, and found that revealed comparative advantage, GDP per capita and annual increase of RMB savings deposits of Chinese residents are not stable series, while after second difference to three series, they were stable series. The revealed comparative advantage index are from 0.37 to 0.78 , and revealed comparative advantage index, GDP per capita and annual RMB increase are with cointegrated. The result has showed that it will make non-equilibrium state back to equilibrium by coefficient of 0.24 in long-term.

\section{Introduction}

The relationship among revealed comparative advantage (RCA), GDP per capita (PRGDP) and household deposit (SBRAI) in Capital-technology-intensive industry is increasingly discussed globally. Some scholars in China argue the RCA of capital intensive industry has a competitive edge in the world, while other researchers did not agree with it. They argued that the RCA presently have an advantage in the labor intensive industry other than in capital intensive industry.

David Ricardo(1870) created the comparative advantage theory as against Adam Smith's absolute advantage theory. It has become one of the main methods in analyzing the trade profit by export trade in and out of a country. A century later, Sweden economist Heckscher and Ohlin provided the dominant theory of factor endowment theory. Later, Haberler(1933), Wassily W. Leintief(1933), Lerner(1932) have improved it. Posoner (1961) use Technology gap theory to explore the merit. Vernon(1966) discuss it by Product life cycle theory.

Paul Krugman(1972) created scale economy and trade theory. Micheal Port raised the competitive strategies, national strategy and advantages of competition. However Krugman reject that Port's view does not be applied in the angle of nations, only can be applied in firms.

Hong(1977) argued the trap of comparative advantages. He insisted that the comparision of cost should be discussed within a country other than out of the country.

Leintief 's mothod of input-output model is a good way. However the basic data of materials is hard to get. So the Balassa $(1965,1989)$ revealed comparative advantage index can be the reflection of trade advantages.

Analysis of these views is a comprehensive analysis of RCA, PRGDP and SBRAI of in-depth theoretical equation models. This paper summarizes the scholars research among RCA, PRGDP and SBRAI, and use vector error correction model, VEC, to explore the relationships.

The innovation of this paper is to use a longer time-series data quantitative analysis to improve the reliability and validity of the study, revise and improve some of the conclusions of previous studies.

The paper is organized as follows, the second part is a theoretical overview of the relationship between the RCA, PRGDP and SBRAI, the third part is the empirical analysis on Chinese RCA, PRGDP and SBRAI, the fourth part draw conclusions. 


\section{Theoretical Overview on the RCA, PRGDP and SBRAI}

According to literatures, the RCA (Balassa,1965,1989) is

$$
R C A_{i j}=\frac{X_{i j} / \sum_{i}^{N} X_{i j}}{\sum_{j}^{N} X_{i j} / \sum_{i}^{M} \sum_{j}^{N} X_{i j}}
$$

$X_{i j}$ is the export of Capital-technology-intensive Products within a country; $\sum_{i}^{N} X_{i j}$ is the total export of the country. $\sum_{j}^{N} X_{i j}$ is the export of Capital-technology-intensive Products in the $\sum_{\text {world. }}^{M} \sum_{j}^{N} X_{i j}$ is the export of the whole world trade.

The purpose is to explore how PRGDP and SBRAI affect the RCA in China. Whereas PRGDP and SBRAI will also have effects on RCA. Any one of the three variables can be the dependent variables and independent variables. Then VEC or VAR models can do it.

If the three variables, RCA,PRGDP and SBRAI, dataset are all stationary series. Many models can be used. If three variables are non-stationary series. We can use difference equations to do integration. To discuss the cointegration of three variables, VEC models are necessary. So This paper using VEC model is to analyze and to determine the correlation among RAC, PRGDP and SBRAI.

\section{Empirical Analysis of capital-intensive product's RCA, PRGDP and SBRAI in China}

\section{Models Construction}

First of all, we have established the basic RCA, PRGDP and SRBAI impact model

$$
\ln \left(R C A_{t}\right)=\alpha+\beta_{t} \ln \left(P R G D P_{t}\right)+\gamma_{t} \ln \left(S B R A I_{t}\right)+u_{t} \quad t=1995,1996, \ldots, 2014
$$

RCA is the reveal competitive advantage index, PRGDP is the index of economic growth. SBRAI represent the source of capital using the annual increase of RMB savings deposits of urban and rural residents (100 million yuan) in China.

Data Collection and Selection

The dataset come from the UN trade sources and Chinese Statistics Bureau. The category of products mainly include goods and services. Here we choose the goods data for RCA closely connecting with goods other than services. The standards of goods are HS, SITC and BEC. We use SITC rev.3. For the rev.4. has a short period. Capital-technology-intensive Products are 5th category and 7 th category of the goods. The dataset of PRGDP and SBRAI in China are from database of Chinese Statistics Bureau.

Model Analysis and testing

ADF Unit Root Test on RCA,PRGDP and SBRAI

In order to obtain intuitive understanding, we first draw charts of three variables (1995-2014) in Fig2, Fig3 and Fig4.

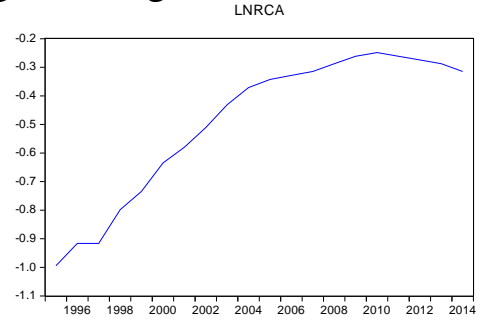

Fig2. Trend of RCA in China Fig3. Trend of China's PRGDP

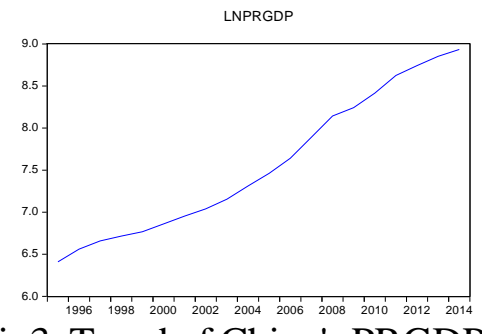

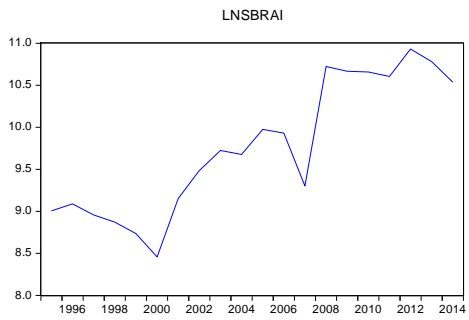

Fig4. Trend of SBRAI in China 
It is clear that the graphs showed some trends. We judges that RCA has no clear trend. So, with unit root test, we have selected the intercept, no trend item unit root test. Analysis of results are in Table 2.

Table 2. ADF test of $\ln (\mathrm{RCA})$

Lag Length: 2 (Automatic - based on SIC, maxlag=4)

\begin{tabular}{lccc}
\hline \hline & t-Statistic & Prob. $^{*}$ \\
\hline \hline Augmented Dickey-Fuller test statistic & -3.732883 & 0.0152 \\
\hline Test critical values: & $1 \%$ level & -3.959148 & \\
& $5 \%$ level & -3.081002 & \\
& $10 \%$ level & -2.681330 & \\
\hline
\end{tabular}

As can be seen, $\mathrm{P}=0.0152$, the test results showed, RCA sequence would accept the null hypothesis which is a non-stationary sequence. Further, we do the ADF test by first difference and second difference. We got $\ln (R C A) \sim I(2)$.

Second, we will determine the condition of sequence of PRGDP. It is clear that the graphs showed some trends. We judges that PRDGP has some trends. So, with unit root test, we have selected the intercept, no trend item unit root test. Analysis of results are in Table 3:

Table 3. ADF test of $\ln (\mathrm{RCA})$

Lag Length: 1 (Automatic - based on SIC, maxlag=4

\begin{tabular}{|c|c|c|c|}
\hline & & $\mathrm{t}$-Statistic & Prob. ${ }^{*}$ \\
\hline \multicolumn{2}{|c|}{ Augmented Dickey-Fuller test statistic } & -4.649136 & 0.0025 \\
\hline \multirow{3}{*}{ Test critical values: } & $1 \%$ level & -3.920350 & \\
\hline & $5 \%$ level & -3.065585 & \\
\hline & $10 \%$ level & -2.673459 & \\
\hline
\end{tabular}

We can see SBRAI sequence would accept the null hypothesis which is a non-stationary sequence. When model adopt second difference equation, $\mathrm{P}=0.0025$, as Table 3 showed, the second difference series are stationary. Further, we do the ADF test by first difference and second difference. We got $\ln (S B R A I) \sim I(2)$.

Third, we will determine the condition of sequence of SBRAI.

It is clear that the graphs showed some trends. We judges that SBRAI has some trends. So, with unit root test, we have selected the intercept, no trend item unit root test. Analysis of results are in Table 4.

Table 4. ADF test of $\ln (\mathrm{PRGPD})$

Lag Length: 1 (Automatic - based on SIC, maxlag=4)

\begin{tabular}{lccc}
\hline \hline & t-Statistic & Prob. $^{*}$ \\
\hline \hline Augmented Dickey-Fuller test statistic & -5.252463 & 0.0008 \\
\hline Test critical values: & 1\% level & -3.920350 & \\
& $5 \%$ level & -3.065585 & \\
& $10 \%$ level & -2.673459 & \\
\hline
\end{tabular}

As can be seen, $\mathrm{P}=0.4646$, the test results showed, SBRAI sequence would accept the null hypothesis which is a non-stationary sequence. Further, we do the ADF test by first difference and second difference. We got $\ln (S B R A I) \sim I(2)$.

Cointegraion by Engle-Granger two steps

There are two methods on cointegration. One mothod is two steps of Engle-Granger (E-G) by ADF tests. Another is Johansen cointegration test based on regressed coefficients.

In order to discuss the cointegration among RCA, PRGDP and SBRAI. We use methods of two steps of Engle-Granger (E-G).

step 1. Estimate the long equilibrum of model (3.1) by OLS. As we have known the CRA,

PRGDP and SBRAI all are $I(2)$. Then it is possible the coinegration exists. We use the equation (3.2)

$$
Y=\beta_{0}+\beta_{1} X+\mu_{t}
$$


If the three variables are cointegration, we can get the coefficient of $\beta_{0}$ and $\beta_{1}$ by OLS.

step 2. Stationary test on estimated error series by ADF test. $\left\{\hat{e}_{t}\right\}_{\text {is }}$ the estimator of deviation in long equilbrum. If the estemated errors of $\left\{\hat{e}_{t}\right\}$ is stationary, then three variables are cointegration, series $\left\{Y_{t}\right\}$ and $\left\{X_{t}\right\}_{\text {is }}(1,1)$ cointegration. So, according to principle of ADF, we have to estimate the autocorrelation model (3.3)

$$
\Delta \hat{e}_{t}=\rho \hat{e}_{t-1}+\varepsilon_{t}
$$

After regression of model (3.1), we obtained the results of unit root tests e1 in Table 5:

Table 5. Unit root test of error

Lag Length: 1 (Automatic - based on SIC, maxlag=4)

\begin{tabular}{lccc}
\hline \hline & t-Statistic & Prob. $^{*}$ \\
\hline \hline Augmented Dickey-Fuller test statistic & -4.643943 & 0.0025 \\
\hline Test critical values: & 1\% level & -3.920350 & \\
& $5 \%$ level & -3.065585 & \\
& $10 \%$ level & -2.673459 &
\end{tabular}

From the results, we can see statistic of ADF is -4.64 , less than critical value -3.07 at significant $5 \%$. It shows the error series is stable, then can proved the RCA, PRGDP and SBRAI are cointegration.

Cointegraion by Johansen and Juselius test

Now, we used the second method of Johansen(1988) and Juselius (1990) test (JJ) to explor the cointegration of three series, RCA, PRGDP and SBRAI.

After JJ test, we got the result in Table 6.

Table 6. Result of JJ test

\begin{tabular}{ccccc}
\multicolumn{6}{l}{ Unrestricted Cointegration Rank Test (Trace) } & & \\
\hline \hline $\begin{array}{c}\text { Hypothesized } \\
\text { No. of CE }(\mathbf{s})\end{array}$ & Eigenvalue & $\begin{array}{c}\text { Trace } \\
\text { Statistic }\end{array}$ & $\begin{array}{c}0.05 \\
\text { Critical Value }\end{array}$ & Prob. $^{* *}$ \\
\hline \hline None * & 0.917188 & 65.73140 & 35.19275 & 0.0000 \\
At most 1 * & 0.571310 & 23.38135 & 20.26184 & 0.0180 \\
At most 2 & 0.410425 & 8.981999 & 9.164546 & 0.0541 \\
\hline \hline
\end{tabular}

We can got two standard cointegraion equations

$\ln (R C A)=1.53219-0.106082 \ln (S B R A I)$

$\ln (P R G D P)=4.458212-1.306875 \ln (S B R A I)$

RCA, PRGDP and SBRAI's VEC Models

Because RCA, PRGDP and SBRAI all are I(2) sequence. The three variable series do have the same integer order, we can establish error correction model (ECM) of RCA, PRGDP and SBRAI. Firstly establish long-term equilibrium equation using the data of the year 1995 to 2014

$$
\ln (R C A)=k_{0}+k_{1} \ln (P R G D P)+k_{2} \ln (S B R A I)+u_{t} \quad t=1,2, \ldots, T
$$

So let residual series $e c m_{t}=\hat{u}_{t}$, as the error correction term, the establishment of the following error correction model is

$$
\Delta \ln (R C A)=\beta_{0}+\alpha e c m_{t-1}+\Delta \beta_{1} \ln (P R G D P)+\Delta \beta_{2} \ln (S B R A I)+\varepsilon_{t}
$$

After the estimation, the result of equation (3.5) is

$$
\Delta \ln (R C A)=-2.146677+0.203796 \ln (P R G D P)+0.012282 \ln (S B R A I)-0.2441 e 1_{t}
$$

By measurement result ECM regression equation, we find that RCA affected their development in the extent of $24.41 \%$. ECM reflects the size of the coefficient of deviation from the long-run equilibrium of readjustment. From 0.24 coefficient estimates we can see, when short-term fluctuations deviate from the long-term equilibrium, it will adjust the intensity of 0.24 , and make non-equilibrium state back to equilibrium. 


\section{Conclusions}

Inspecting on Chinese revealed comparative advantage, PRGDP and SBRAI, the results are: Chinese revealed comparative advantage, PRGDP and SBRAI all are not stability sequences. Whereas by second difference, all are stationary sequences. When the short-term fluctuations deviate from the long-run equilibrium, adjustment of the PRGDP and SBRAI back to long term equilibrium will be -0.24 .

\section{Acknowledgement}

This research was financially supported by the Science Foundation of Ministry of Education of China(Grant No.11YJA630122 ); Wuhan Textile University Research Team on Textile Industry Development and Innovation in China (Grant No.201316-27); Research Center of Enterprises Decision Support, Humanities and Social Science Base in Hubei Province.

\section{References}

[1] Salike N, Lu B. An Examination of Nepal's Export Choice based on Revealed Comparative Advantage[J]. NRB Economic Review, 2015, 27(1): 75-89.

[2] Setyari N P W, Widodo T, Purnawan M E. Comparative advantage dynamism of Indonesian export products[J]. The Journal of Developing Areas, 2016, 50(5): 57-69.

[3] Kim T, Meng D. Dynamic Changes of China's Export Specialization[J]. Modern Economy, 2015, 6(05): 633.

[4] Kim S J, Kim G S. Changes in the Revealed Comparative Advantage of South Korea and Her Major ASEAN Trading Countries[J]. Seoul Journal of Economics, 2015, 28: 325-358.

[5] Setyari N P W, Widodo T, Purnawan M E. Industrial Capital Intensity and Comparative Advantages Dynamism of Indonesian Export Products[J]. Jurnal Ekonomi Pembangunan: Kajian Masalah Ekonomi dan Pembangunan, 2015, 16(2): 107-120.

[6] Karaduman H A, Gonel F. Dirty industries' competitiveness in EU's new members[J]. World Journal of Science, Technology and Sustainable Development, 2016, 13(3).

[7] Thomas L. Vollrath, A theoretical evaluation of alternative trade intensity measures of revealed comparative advantage, Review of World Economy, Volume 127, Issue 2, June 1991, pp 265-280 [8]Bela Balassa, Trade Liberalisation and "Revealed" Comparative Advantage1,The Manchester School, Volume 33, Issue 2, May 1965, pages 99-123

[9] Moncarz P, Olarreaga M, Vaillant M. Regionalism as Industrial Policy: Evidence from MERCOSUR[J]. Review of Development Economics, 2016, 20(1): 359-373.

[10] Harry P. Bowen, On the theoretical interpretation of indices of trade intensity and revealed comparative advantage, Weltwirtschaftliches Archiv,June 1980, Volume 116, Issue 2, pp 315-321 [11] Lin J Y, Yu M. Industrial upgrading and poverty reduction in China[J]. Structural change and industrial development in the BRICS, 2015: 93-118.

[12] Utami Y. What are the Gain And Loss of Comparative Advantage Among Asean[J]. Equilibrium: Jurnal Ekonomi Syariah, 2016, 2(1).

[13] V Serin, A Civan, Revealed comparative advantage and competitiveness: A case study for Turkey towards the EU, Journal of Economic and Social Research, 2008

[14] Tamberi, Revealed' Comparative Advantage Revisited: An Analysis of Relative Export Shares of the Industrial Countries, 1953-1971, The Manchester School, Volume 45, Issue 4, December 1977 ,PP. 327-344

[15] Ban I M. Measuring trade specialization dynamics: the case of Romania and Bulgaria[J]. Empirica, 2016: 1-20.

[16] R Yu, J Cai, PS Leung, The normalized revealed comparative advantage index, The Annals of Regional Science, 2009 
[17]M Krishnan, A Srinivasan, Do supervisory inputs matter in a capital-intensive industry? Some evidence from a Japanese car transplant, Managerial \& Decision Economics, 1997, 18(3):235-245 